\title{
DIMENSI AKHLAK DALAM SHALAT
}

\section{Telaah Teologis-Filosofis}

\section{Sehat Sultoni Dalimunthe}

STAIN Malikussaleh Lhokseumawe Jl.Tgk.Chik Ditiro No.9 Lhokseumawe Aceh Utara Email: borneo_ra@yahoo.co.id

\begin{abstract}
ABSTRAK
Akhlak mencerminkan identitas dan kualitas individu, masyarakat, suku dan bangsa bahkan menjadi parameter harkat dan martabat peradaban seluruh umat manusia sepanjang zaman. Inti ajaran Islam adalah akhlak. Konsep tersebut dinyatakan dalam sebuah hadis bahwa Allah SWT tidak semata-mata mengutus Muhammad SAW kecuali untuk satu tugas penting yakni memperbaiki akhlak umat manusia. Pendidikan Islam yang memfokuskan pada pembentukan akhlak menjadi sangat penting. Dalam pendidikan Islam berbasis akhlak dipelajari perilaku terpuji agar diamalkan dan perilaku tercela dihindari dan dijauhi oleh semua murid. Secara teologis, menelaah akhlak dapat dilakukan dengan menggunakan pendekatan teologis dan filsafat secara bersama-sama. Agama (wahyu) berasal dari Allah dan filsafat (akal) juga berasal dari Allah SW'T. Secara metodologis, akhlak dapat dipelajari dengan menggunakan metode tajrîbi (induktif) dan metode qiyâs (deduktif). Secara didaktis, akhlak dapat diajarkan, baik melalui suri teladan maupun pembiasaan.
\end{abstract}

Kata Kunci: Akhlak, Pendidikan, Shalat

\begin{abstract}
Akblak reflects the identity and quality of the individual, society, tribe and nation and even the parameter of dignity of all human civilization throughout the ages. The essence of Islam is akblak. The concept is stated in the Hadith saying that Allah not merely sent Muhammad SAW except for an important task to edify mankind. Islamic education that focuses on the formation of akblak is essential. Akblak-based Islamic education studies and practices good behaviour and teaches students to avoid reprehensible behavior. Theologically, examining the akblak can be done by using theological and philosophical approaches together. Religion (revelation) from God and philosophy (reason) come also from Allah swt. Methodologically, morals can be studied by using method tajribi (inductive) and method of qiyas (deductive). In didactic, akblak can be taught, through role models and babituation.
\end{abstract}

Keywords: Akblak, Education, Shalat 


\section{PENDAHULUAN}

Dalam buku-buku yang membahas akhlak, para ahli sering mengutip hadis, "innama bu'itstu li utammima makârim al-akblâq". Hadis ini dikutip pula oleh Zuqzuq dalam Muqaddimah fî 'Tlmi al-Akhlâq. Hal ini menunjukkan bahwa akhlak merupakan misi utama kehidupan manusia. Begitu urgennya akhlak bagi kehidupan sehingga akhlak diidentikan dengan misi kemanusiaan. Dalam literatur Indonesia, pembahasan akhlak belum banyak ditemukan. Para ahli pendidikan Indonesia lebih banyak menyebutnya dengan pendidikan karakter atau budi pekerti. Ketika mereka membicarakan akhlak pun, yang sering dibahas adalah akhlak praktis seperti sabar, syukur, iffah, menderma, dan rahmah. Masih sulit ditemukan pendidikan dan pengajaran akhlak dalam konteks yang lebih idealis yang menggambarkan al-akhlâq al-karimah secara laten. Pembahasan akhlak secara filosofis juga jarang disentuh (Kamal, 1999: 11). Satu-satunya karya yang sering dijadikan rujukan pembahasan secara filosofis adalah buku terjemahan Tabdzî́b al-Akblâq karya Ibn Miskawaih. Ia mengisyaratkan bahwa buku tersebut mestinya bukan menjadi satu-satunya rujukan para penulis akhlak berikutnya. Dalam filsafat Islam klasik selain karya Ibn Miskawaih Tahdzî́b alAkhlâq ada karya lain yaitu karya al-Razi, yakni al-Thibb al-Mansûr dan al-Thibb alRûhani (Kamal, 1999: 12-13).

Syauqy Bay secara tegas mengatakan:

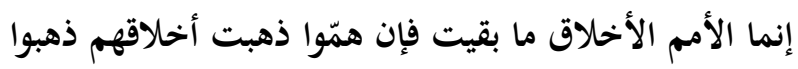

Sesunggubnya eksistensi ummat itu dilihat dari abklaknya. Jika Akblak tidak mereka miliki, sesunggubnya mereka tidak memiliki eksistensi (Mabmud Yunus, $1407 \mathrm{H:}$ :21)

Akhlak menjadi parameter yang sesungguhnya untuk mengukur kualitas keberwujudan seseorang dan sekelompok orang bahkan menjadi indikator tinggi rendahnya peradaban suatu bangsa. Jika suatu umat/bangsa dihuni oleh orangorang yang berakhlak mulia maka ada kecenderungan bangsa tersebut memiliki peradaban yang maju/tinggi. Peradaban yang maju pun mendukung terciptanya manusia yang berakhlak mulia. Berarti keduanya saling berhubungan secara timbal balik. Namun di antara keduanya terdapat semacam "daerah tak bertuan" yang dapat menjadi objek rebutan antara akhlak dengan peradaban. Daerah tak bertuan tersebut adalah pendidikan. Pendidikanlah yang dapat menentukan jenis kurva yang akan dibentuk, apakah netral/normal, condong ke kiri (tercela/biadab) atau ke kanan (terpuji/beradab). Kunci membina akhlak dan membangun peradaban adalah pendidikan. Tulisan ini bermaksud menggambarkan cara-cara pendidikan berperan dalam membentuk ruh seseorang sehingga berakhlak dan identitas kolektif suatu bangsa sehingga beradab. Subjek utama pendidikan adalah manusia. Fase penting pembentukan akhlak dan peradaban manusia adalah fase usia dini antara 1 sampai dengan 5 
tahun. Sudut pandang yang digunakan untuk membahas persoalan dalam tulisan ini adalah filsafat.

\section{PEMBAHASAN}

\section{Teologi Akhlak}

Ibn Miskawaih mendefinisikan akhlak sebagai keadaan jiwa seseorang yang mendorong untuk berbuat tanpa melalui proses berpikir dan pemahaman. Akhlak berarti melibatkan alam bawah sadar. Ilmu yang mempelajarinya disebut ilmu akhlak yang berarti, harus melibatkan kajian psikologis/psikoanalisis tentang alam bawah sadar. Menurut Muhammad Abduh, ilmu akhlak adalah ilmu yang membahas keutamaan-keutamaan dan cara mendidik manusia agar dapat memperolehnya. Ilmu akhlak juga membahas perilaku-perilaku tercela dan cara mendidik manusia untuk berhenti melakukannya. Ilmu akhlak tersirat dalam alQuran, hadis, atsar sahabat dan tabi'in. Maka secara teologis ada empat sumber kajian ilmu akhlak.

Muhammad Abduh terkesan dengan ucapan Umar bin Khattab saat ada seorang isteri yang dengan terus terang mengatakan kepada suaminya bahwa ia tidak menyukai (mencintai) suaminya. Umar bin Khattab berkata; "Jika ada di antara kalian (isteri-isteri) yang tidak menyukai laki-laki (suami), maka kalian jangan perhitungkannya lagi (jangan berterus terang sehingga suaminya merasa sakit hati dengan keterusterangannya itu), karena sedikit sekali kehidupan rumah tangga yang dibangun atas dasar kasih sayang. Sesungguhnya yang paling mengesankan bagi manusia adalah posisi/jabatan dan akhlaknya". Ridha mengomentari bahwa larangan tersebut tidak akan terasa menyakitkan bagi orang yang mendengarnya bahkan akan berkumandang dengan indahnya karena keluar dari mulut orang (Umar) yang berakhlak sangat mulia (Ridha, $1365 \mathrm{H}$ : 41).

Dari cerita Umar bin Khattab di atas dapat dimaknai bahwa aspek terpenting dari akhlak bukan kata-katanya tetapi perilaku yang sebenarnya dari orang yang berpetatah-petitih tentang akhlak. Dipelajarinya ilmu akhlak bukan semata-mata untuk dipahami tetapi untuk diamalkan sebaik mungkin sehingga dapat ditauladani oleh semua orang. Amin (tt: 15) menguatkan pernyataan tersebut dengan mengatakan bahwa akhlak adalah kebiasaan berkehendak. Kebiasaan adalah perbuatan/perilaku/amal yang dilakukan secara berulang-ulang dan sifatnya refleks tanpa melalui proses pertimbangan yang masih merasa bimbang untuk dilakukan atau tidak (reflektif). Sifat refleks dari perbuatan yang berulang-ualng tersebut lama kelamaan membentuk kesadaran etik dan moral (Purbakawatja, 1978: 9). Akhlak bukan (kesadaran) concious mind, tetapi (subkesadaran) subcuncious mind, bahkan cenderung bermakna quantum, yakni semacam titian loncat yang lentur namun dapat melesatkan orang yang memijaknya. Anis yang menegaskan bahwa akhlak adalah perbuatan baik 
dan/atau buruk yang tanpa membutuhkan perhitungan dan pertimbangan untung atau rugi sesaat jika ditinggalkan atau dilakukan (Anis, 1972: 202).

\section{Epistemologi Akhlak}

Sumber pengetahuan akhlak seringkali dipersoalkan orang. Zuqzuq (1983: 13) menyamakan Akhlak dengan moral dan etika. Menurutnya, sumber utama pembentuk akhlak adalah teologi/agama/wahyu yang tertuang dalam kitab Allah (Taurat, Injil, Jabur dan al-Qur'an). Umat Islam berpegang pada kitab suci al-Qur'an berarti sumber akhlak umat Islam adalah al-Qur'an, hadis, dan Atsar sahabat dan tabi'in. Akan tetapi kajian terhadap Akhlak tidak berarti tidak memerlukan telaah ilmiah sebab telaah ilmiah pun pada dasarnya berasal dari Allah SWT. Namun Zuqzuq menambahkan bahwa akhlak dapat bersumber dari filsafat atau hasil pemikiran manusia. Untuk menentukan akhlak (baik dan buruk, kemuliaan dan kehinaan) seseorang dapat ditelusuri berdasarkan analisis rasio atau akal. Menurutnya, akal dipandang mampu membedakan perbuatan baik dengan perbuatan buruk yang melekat pada manusia. Jika pengertian akhlak berdasarkan temuan akal itu benar dan lurus maka seyogyanya agama pun mengakui kebenaran tersebut (Zuqzuq, 1983: 13).

Dalam pemikiran pendidikan Islam, hal baik dan buruk menurut pendapat Zuqzuq cenderung beraliran Mu'tazilah atau Maturidiyah Samarkand. Bagi Zuqzuq, tidak ada pertentangan antara akhlak berdasarkan agama dengan akhlak berdasarkan akal (filsafat). Akal manusia adalah hidayah Allah dan wahyu juga berasal dari Allah, maka tidak mungkin terjadi pertentangan di antara keduanya, sebab bagaimanapun juga keduanya memiliki sumber yang sama, yaitu Allah. Mengutip pendapat al-Ghazali, dalam Ma'ârij al-Quds, Zuqzuq mengatakan:

"Ketahuilah bahwa akal tidak akan benar tanpa syariat dan syariat tidak akan benar tanpa akal. Akal bagaikan fondasi, sementara syariat bagaikan bangunan. Fondasi tidak akan bermakna jika tanpa ada bangunan. Bangunan pun tidak akan berdiri tanpa ada pondasi. Syariat itu pada dasarnya akal jika ditinjau dari luar. Sedangkan akal adalah syariat jika ditinjau dari dalam. Keduanya berbeda (muta'âridhâni) tetapi saling menguatkan. Karena keduanya saling menguatkan, maka keduanya disebut dalam al-Qur'an sebagai; nûrun 'ala nûr, nûr al-aql wa nûr asy-syar'i. sesungguhnya tidak ada pertentangan antara al-ulum al-diniyah dengan al"ulûm al-"aqliyah" (Zuqzuq, 1983: 15).

Akal dan wahyu (mushaf) bersumber dari Allah SWT yang mutlak, tetapi hasil temuan/tafsiran akal terhadap mushaf mungkin salah mungkin benar/relatif. Karena itu secara akal rumusan tentang moral/etika/akhlak yang semuanya melalui perantara akal tidak akan bertentangan dengan wahyu. Dalam pelaksanaannya bisa saja bertentangan, tetapi yang menentukan bukan akal atau mushaf tapi potensi buruk manusia. 
Dalam pandangan Kamal (tt: 15), Ibn Miskawaih dipengaruhi oleh pemikiran etika Plato dan Aristoteles yang secara filosofis merupakan temuan akal namun sejalan dengan mushaf. Kartanegara (2005: 56-58) membuktikan bahwa temuan/ungkapan Plato sejalan dengan akhlak yang ada dalam mushaf. Plato ditanya, "Mungkinkah engkau disebut seorang pengangguran?" Dia menjawab, "Mungkin saja, yaitu jika kita dapat melakukan kebaikan kepada manusia, tapi kita tidak melakukannya. "Apakah pemberian yang dapat disumbangkan oleh setiap orang?" Plato menjawab, "Merasa senang jika kebaikan terjadi pada orang lain."

Jawaban Plato seirama dengan firman Allah SWT yang tersurat dalam mushaf al-Qur'an yaitu; fastabiqu al-khairât, dan sejalan dengan semangat Hadis, khair al-nas anfa'ubum li al-nas. Ia bagaikan doa, wajalil hayata riyadatan lana min kulli khair. Padahal Plato hidup jauh sebelum lahir agama Islam. Karena itu Kartanegara, membolehkan orang menerjemahkan kata God untuk kata Allah. Jika kita yang sudah mengenal Islam dan al-Qur'an mengetahui makna hikmah yang diungkapkan Plato, tentu kita tidak dianggap sebagai manusia istimewa, tetapi Plato tidak membaca (kitab) al-Qur'an dan hadis, maka ia pantas disebut manusia hebat/filosof. Pada saat orang berkata tentang filsafat, sering tidak berada pada makna yang sebenarnya dari sang filosof. Ia hanya merumuskan ulang pemikiran filosof. Ia hanya pandai berkata-kata/berorasi/beretorika tanpa disertai pengamalan nyata dalam kehidupan sehari-hari. Orang seperti ini hanya layak disebut pengkhotbah bukan filosof.

Dalam konteks pemikiran/filsafat pendidikan Islam, Plato adalah seorang sufi. Umumnya manusia sekarang dihinggapi penyakit materialistik, iri hati dan kedengkian. Plato justru berlaku bijak dengan mensyukuri kebaikan yang diterima orang lain. Rasa empati/simpati atas kesedihan yang menimpa orang lain hingga ikut meneteskan air mata sudah merupakan bagian dari akhlak mulia, apalagi jika ikut berpartisipasi nyata dengan meringankan beban mereka.

\section{Metode Pendidikan Akhlak Perspektif Teologis-Filosofis}

Sokrates adalah pendiri ilmu moral. Menurutnya, moral dapat diubah melalui pendidikan. Semakin tinggi ilmu seseorang, ia semakin bermoral. Ilmu bagi Sokrates merupakan kemuliaan, sedangkan kebodohan merupakan kehinaan. Al-Ghazali yang berpendapat bahwa sangat mungkin mengubah moral dengan pendidikan. Sebagaimana sabda Rasul, Hassinû akblâqakum: "Perbaiki akhlak kalian." (Zuqzuq, 1983: 15).

Sokrates ditanya, "Mengapa engkau tidak pernah bersedih?" Dia menjawab, "karena aku tidak memiliki benda-benda yang kehilangannnya membuatku bersedih." Dia ditanya lagi, "Mengapa Anda tidak berhasrat kepada benda-benda yang menyokong hidupmu?" Dia menjawab, "karena aku takut diriku dikuasai benda-benda itu, sehingga mereka membuatku terancam (Kartanegara, 2005: 58). 
Dialog di atas ingin menjelaskan bahwa kemiskinan itu indah, seperti sufi yang tidak menyukai kemegahan. Al-Adawiyah, seorang pencetus mahabbah dalam tasauf, hidup dalam kemiskinan dan menolak segala bantuan materi bahkan dalam doanya kepada Allah SWT, ia tidak mau meminta materi (Nasution, 1995: 72). Konsistensi Sokrates untuk hidup miskin dapat dilihat dari uangkapannya ketika ditanya, "Mengapa engkau tidak punya rumah?" Dia menjawab, "Sebab aku malu merebut sepetak tanah dari Zat yang memiliki seluruh bumi. Padahal Dia sangat pemurah dan baik padaku (Kartanegara, 2005: 58). Tentu tidak bijak jika orang memahami kemiskinan sebagai cita-cita atau obsesi. Akan tetapi, sikap terlalu mencintai materi sering melalaikan orang untuk selalu mengingat Allah.

Spencer menyatakan bahwa pelajaran tidak dapat mengubah akhlak seseorang. Baginya, pelajaran tidak memiliki kekuatan untuk mengubah akhlak. Spencer beralasan, seseorang yang terlalu memercayai pelajaran tidak bisa mengubah akhlak karena orang-orang yang terlalu terpelajar dan terlalu bersinar dengan pikirannya cenderung tidak berakhlak. Sebaliknya, orang yang bodoh lagi buta huruf, karena istiqâmah maka dapat berperilaku mulia. Hal ini terjadi karena orang yang terlalu terpelajar biasanya memiliki beragam rekayasa/akal-akalan (cunning of reason). Sementara, orang yang biasa saja dan lugu, tidak memiliki ruparupa perangkat untuk merekayasa perkataan dan perbuatan namun mereka beradab karena kejujurannya. Dalam pandangan Sokrates, orang yang berpendidikan tinggi namun tidak memiliki akhlak yang baik sebetulnya belum berilmu dan berpendidikan.

Daradjat (1977: 13) berpendapat bahwa akhlak bukan mata pelajaran atau ilmu pengetahuan semata. Ia merupakan pembiasaan-pembiasaan. Akhlak yang baik itu hanya bisa diperoleh dengan praktik berakhlak mulia. Akhlak juga bukan merupakan warisan genetik (Mahmud Hamdi Zuqzuq, 1983: 21).

Ibn Miskawaih mengatakan bahwa mengubah akhlak seseorang dengan ilmu, hendaknya disertai dengan pendekatan agama dan filsafat. Sinergi ketiganya bermanfaat besar dalam membentuk akhlak. Allah berfirman, "dzakkir, fainna dzikera tanfa'ul al-mu'minin (Q.S. al-Maidah: 55). Binatang liar dan buas bisa mengubah perilakunya dengan perilakunya pula.

Pendidikan akhlak dapat mengubah perilaku, tetapi tidak secara otomatis dengan pendidikan tersebut manusia dapat menjadi mulia. Orang yang belajar tasauf tidak semuanya berlaku seperti sufi. Semua bergantung pada kesiapan, kecenderungan, dan bakat perilaku praktisnya dalam kehidupan sehari-hari. Aristoteles mengatakan bahwa keinginan kuat anak adalah untuk tetap berbuat baik dan hati yang mulia dibentuk oleh fitrah yang baik. Itu adalah janji-Nya (Zuqzuq, 1983: 22).

Daradjat (1977: 13-17) mengatakan bahwa ada delapan faktor penyebab kemerosotan akhlak anak. Salah satunya adalah bahwa pendidikan akhlak di rumah tangga, sekolah, maupun masyarakat tidak terlaksana sebagaimana mestinya. Artinya tidak ada pembinaan yang serius di antara tiga lingkungan 
pendidikan tersebut. Pembinaan akhlak seharusnya dilaksanakan sejak dini sesuai dengan kemampuan dan umurnya. Konsep pendidikan akhlak berdasarkan kemampuan dan umur ini perlu dibangun dan dikembangkan konsepnya secara terus-menerus seiring dan sejalan dengan perkembangan anak itu sendiri. Pada masa pranatal pun mestinya sudah dikenalkan pendidikan akhlak melalui kedua orang tuanya yang senantiasa berperilaku baik dalam kesehariannya. Setelah lahir sampai masa pendidikan anak usia dini hingga masa pendidikan dasar, ia lebih banyak bersama dengan ibunya. Karena itu, sumber pendidikan akhlak anak pada masa ini banyak diperankan oleh ibunya. Seorang ibu bukan hanya dianjurkan memiliki wawasan yang luas tentang cara/metode mendidik anak yang baik dan benar tetapi seorang ibu juga harus bermoral baik. Dalam pendidikan akhlak dibutuhkan contoh atau teladan (Yunus, t.t: 49).

Umumnya, orang-orang yang berakhlak mulia merupakan keturunan dari para orang tua yang berakhlak mulia juga. Karena itu, anak sering mengidolakan orang tuanya. Jika orang tuanya berakhlak mulia maka ada kecenderungan anak pun mengidolakan orang tuanya yang berakhlak mulia, walaupun tidak semuanya begitu. Misalnya, Kan'an, putra Nabi Nuh, tidak mengidolakan/mengikuti akhlak bapaknya yang berakhlak mulia, baik dan bijaksana. Sebaliknya, Nabi Ibrahim tidak mengikuti jejak ayahnya yang profesinya membuat patung sesembahan pengikut Raja Namruz. Dalam sudut pandang kajian akhlak, ayah Nabi Ibrahim termasuk manusia tidak berakhlak karena lebih takut kehilangan pekerjaannya sebagai pembuat patung dan takut pada kekuasaan Namruz yang zalim daripada takut kepada Tuhannya Ibrahim. Pengganti orang tua di sekolah adalah guru. Saat anak memasuki usia sekolah, ia mencari pigur teladan kepada guru-gurunya. Jika guru berakhlak, maka ada kecenderungan anak pun berakhlak. Sebaliknya, jika guru tidak berakhlak, misalnya bergaya preman; membentak, memukul dan melakukan tindak kekerasan lainnya, maka anak cenderung mengikuti perilaku gurunya menyelesaikan persoalan yakni dengan kekerasan pula. Akibatnya, siswa gemar melakukan tawuran dan tindak kekerasan lainnya seperti perpeloncoan dalam kelompok geng motor. Pepatah, "guru kencing berdiri, murid kencing berlari" betul-betul dapat tuahnya. Guru tidak bisa mendidik murid untuk beramal dan berbuat ikhlas sementara, ia sendiri mengajar tidak dengan sepenuh hati, kurang profesional atau hanya sebatas menggugurkan kewajiban sebagai guru yang tugasnya mengajar. Tidak layak orang berjerawat menjual obat jerawat dan tidak layak guru agama Islam yang tidak memiliki teladan ikhlas mengajarkan ikhlas kepada muridnya.

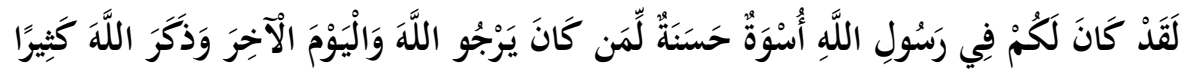

Sesunggubnya telah ada pada (diri) Rasulullah itu suri teladan yang baik bagimu (yaitu) bagi orang yang mengharap (rahmat) Allah dan (kedatangan) hari kiamat dan dia banyak menyebut Allah (Q.S. al-Ahzab [33]: 21) 
Rasulullah SAW adalah sosok teladan dalam hal pendidikan akhlak. Rasulullah SAW mungkin tidak memiliki teori tentang pendidikan akhlak yang ilmiah dan secara sistematis dipelajari melalui lembaga akademik-formal, tetapi ia berakhlak mulia. Akhlaknya bersatu padu dengan kepribadiannya dan tercermin langsung dalam tingkah laku sehari-harinya. Para sahabat tanpa diperintah pun langsung meneladaninya. Para Tabi'in pun terus menggali teladan Rasulullah SAW. Mereka digelari oleh Rasulullah sebagai umat sebaik-baik zaman.

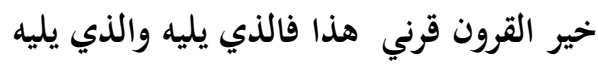

Sebaik-baik masa adalab masaku ini, lalu masa sesudabnya, lalu masa sesudahnya (H.R. Bukhari Muslim). Dalam filsafat pendidikan Islam, ada dua metode praktis pendidikan akhlak, yaitu; 1) metode tajrîbi dan 2) metode 'âdât al-irâdah. Metode tajrîbi mendasarkan diri pada metode induktif Francis Bacon (1561-1626 M) dan filsafat empirisisme John Locke (1632-1704 M) Maqâlah fi al-'Aqli al-Basyari (1690). Metode ini mengandaikan bahwa membina akhlak pada dasarnya berbagi pengalaman antara guru dengan murid. Guru adalah fasilitator/cermin bagi murid dalam menghayati peristiwa kehidupan. Hal yang buruk/tercela yang dialami oleh guru dapat dihindari oleh murid. Hal yang baik/terpuji yang dialami oleh guru dapat ditiru dan dikembangkan oleh murid. Metode induktif adalah cermin bagi murid atas pengalaman dan pengamalan hidup sehari-hari gurunya. Metode kedua, 'âdât al-irâdah adalah metode rasional yang menggunakan pendekatan deduktif. Metode ini mendasarkan diri pada filsafat Aristoteles tentang logika (384-322 SM). Menurut metode ini, akhlak itu pada dasarnya perilaku yang berulang-ulang. Akhlak dapat dikatakan sebagai kebiasaan ('âdât alirâdah) seseorang dalam berperilaku sehari-hari (Harahap dan Lubis, 2005: 8).

Acuan perilaku yang harus diajarkan/dilatihkan secara berulang-ulang adalah norma. Dalam konteks pendidikan Islam norma yang dimaksud adalah alQur'an dan hadis. Ketika al-Qur'an memerintahkan manusia untuk berbuat jujur dan adil maka guru mendoktrinkan perintah tersebut lalu secara sistematis melatihkan kepada murid contoh-contoh perilaku jujur dan adil. Misalnya, ketika ujian, ada siswa yang saling menyontek dalam menjawab soal, guru menghukum dengan cara mendiskualifikasi baik murid yang menyontek maupun yang dicontek. Ini contoh guru memperlakukan muridnya dengan adil dan jika ada kasus yang sama terulang maka guru harus konsisten memberikan hukum yang persis sama dengan yang pertama sambil sesekali memperingatkan bahwa itu bertentangan dengan agama (berdosa). Jika metode keduanya digabungkan maka akan membentuk metode pendidikan akhlak kombinasi/dialektis/metode deduktif-induktif. Dalam pelaksanaannya, guru sering menggunakan metode keduanya secara silih berganti atau bersamaan sesuai dengan situasi dan kondisi yang dialami oleh sekolah masing-masing dan bergantung pada kasusnya.

Akhlak adalah perilaku yang secara spontan dilakukan oleh seseorang tanpa mengalami proses berpikir yang panjang karena sudah bersifat otomatis. Artinya akhlak tidak dibuat-buat. Akhlak bukan semata-mata berbuat kebaikan. 
Akhlak adalah perbuatan baik itu sendiri. Orang berakhlak mulia pasti orang baik, karena ia selalu (berusaha) berbuat baik. Orang yang berbuat baik, apalagi hanya sesekali saja, belum tentu orang itu baik dan berakhlak mulia. Boleh jadi perbuatan baik yang dilakukannya justru bermaksud jahat. Misalnya, suatu saat ada seorang asing dewasa memberi permen pada seorang murid RA/TK. Orang asing itu telah berbuat baik dengan memberi permen pada murid tadi. Tapi tujuannya bukan untuk kebaikan, sebaliknya untuk kejahatan sebab orang asing itu bermaksud menculik murid tadi. Faktor yang sangat mempengaruhi pembentukan akhlak seseorang adalah lingkungan. Ibn Khaldun mengatakan, "al-insanu madaniun bi al-thab'i, manusia dibentuk oleh lingkungannya (Ibn Khaldun, tt: 41), baik lingkungan keluarga, sekolah/madrasah maupun masyarakat. Faktor keturunan/genetika hanyalah potensi bagi anak tersebut untuk berbuat baik atau buruk. Faktor tersebut dapat menurunkan sifat-sifat jasmani, akal, adab orang tua, atau kakek-nenek mereka setelah mendapat rangsangan dari lingkungan yakni lingkungan keluarga. Karena itu, meskipun masih dalam kandungan, ibunya dan anggota keluarga lainnya selalu berupaya menjadi manusia berakhlak mulia, agar anak yang dikandung oleh ibunya kelak menjadi manusia berakhlak mulia pula (Zuqzuq, 1983: 27-32).

\section{Dimensi Akhlak dalam Shalat}

Sabtani, dalam Atsaru Ta'lim al-Qur'ân al-Karîm 'ala al-Fard wa al-Mujtama' (tt: 5) mengupas tuntas hubungan antara pendidikan, akhlak dan al-Qur'an. Ia membahas bahwa ayat-ayat yang berkenaan dengan ibadah berhubungan dengan pendidikan dan akhlak. Ayat-ayat yang berkenaan dengan muamalah pun berhubungan dengan pendidikan dan akhlak. Ayat-ayat yang berisi tentang hukum perdata juga berhubungan dengan pendidikan dan akhlak. Ayat-ayat jinâyah dan dauliyah juga demikian. Pendeknya semua ayat berhubungan dengan pendidikan dan akhlak.

Dalam konteks beribadah, khususnya shalat, sangat berhubungan dengan pendidikan dan akhlak. Dalam mendirikan shalat, "Wa aqimi al-shalata" (Q.S. alAnkabut: 45) dibutuhkan kesabaran. Kesabaran adalah pintu masuk kepada "rumah akhlak". Ketika hendak memulai mendirikan shalat, Rasulullah selalu berdoa:

\section{اهدني لأحسن الأخلاق لا يهدي لأحسنها إلا أنت، واصرف عني سيئها إنه لا يصرف سيئها إلا

"Ya Allah, berilah aku bidayah agar dapat memperbaiki akblakku, karena sesunggubnya tidak ada yang bisa memperbaikinya melainan Engkau, dan palingkan segala keburukan dariku, sebab tidak ada yang mampu memalingkannya melainkan Engkau."

Allah SWT menghubungkan perkataan yang baik dengan shalat. Menurut Sabtani, orang yang mendirikan shalat sebenarnya berikrar pada dirinya sendiri 
bahwa ia akan berkata baik kepada manusia bukan saja kepada sesama Mukmin namun juga kepada orang non Mukmin. Al-Naisaburi telah mendukung teori berkata baik itu dengan mengutip ayat al-Qur'an. Berarti, ada penekanan bahwa dalam pendidikan akhlak membiasakan shalat yang baik dan benar akan memengaruhi aspek kejiwaan dan perilakunya karena shalat adalah berintrospeksi diri untuk selalu berbuat baik dan menghindari perbuatan jahat. Oleh karena itu, sejak Adam, leluhur manusia hadir di bumi ini, manusia tidak pernah berhenti diperintahkan untuk selalu shalat kepada Allah SWT. Dari masa ke masa manusia selalu diperintahkan untuk melaksanakan shalat, intinya agar berbuat baik. Perbedaan waktu karena berbeda daerah, wilayah dan zaman bukan menjadi penghalang bagi manusia untuk senantiasa berkomunikasi dengan Allah SWT. Sebelum Nabi Muhammad SAW Isra' dan Miraj, dan mendapat perintah untuk mendirikan shalat sebenarnya kaum Muslimin sudah terbiasa melakukan shalat (Jabbar, t.t: 40).

Penelitian Prawitasari (1989), menemukan bahwa salah satu fungsi shalat adalah mengurangi kecemasan. Dalam gerakan shalat terdapat unsur relaksasi otot. Dengan mendirikan shalat yang benar serta membiasakannya, seseorang telah mendidik dirinya sendiri dengan akhlak ketenangan dan menghindari kecemasan yang tidak perlu. Kecemasan merupakan penyakit abadi manusia. Manusia bisa cemas karena miskin, sehingga ia korupsi, cemas ditolak gadis idaman, sehingga ia pergi ke dukun, dan cemas tidak mampu bersaing, sehingga ia melakukan kolusi dan nepotisme. Shalat juga berfungsi sebagai media meditasi dan melatih konsentrasi. Meditasi adalah terapi alternatif untuk menyembuhkan penyakit-penyakit jiwa seperti; depresi, rasa takut, rasa sedih, dan stress. Dalam meditasi, gelombang otak lebih banyak mengeluarkan gelombang-gelombang alfa yang berhubungan dengan ketenangan atau kondisi rileks (Haryanto, 2003: 62).

Orang yang berakhlak buruk adalah orang yang tidak sehat jiwa. Untuk itu, mendidik anak menegakkan shalat yang baik dan benar secara berulang-ulang sesuai dengan tuntunan agama, wajib maupun sunat, pada dasarnya telah mendidik diri dengan akhlak. Ketika seseorang secara empiris rajin shalat namun masih tetap berbuat zalim, berarti shalatnya belum sempurna. Shalat adalah proses, maka ia harus terus menyempurnakan baik gerakan maupun amaliah shalatnya. Sokrates berkata, kehilangan harta bisa membuat orang bersedih. Kesedihan yang berkepanjangan melahirkan energi negatif yang dapat menghilangkan nyawa dirinya maupun nyawa orang lain. Dalam shalat, terdapat salam yang merupakan tanda bahwa secara formal shalat berakhir namun menurut Madjid, itu justru awal untuk berbuat baik karena salam adalah simbol horizontal untuk terus berbuat kebaikan/peduli kepada sesama manusia bahkan terhadap alam semesta (Madjid, 1995: 399).

Shalat merupakan auto sugesti. Auto sugesti adalah suatu upaya membimbing diri pribadi, melalui proses pengulangan rangkaian ucapan secara rahasia kepada diri sendiri, sehingga memupuk keyakinan diri untuk selalu berbuat baik dan lebih baik lagi. Bacaan shalat dapat bernilai auto sugesti, karena 
di dalamnya terdapat bacaan dan gerakan berulang. Dalam shalat dzuhur, bacaan al-Fatihah dibaca empat kali. Bacaan al-hamd saja diucapkan sebanyak 25 kali yakni dalam; doa iftitâh satu kali, al-Fâtihah empat kali, ruku' empat kali, i'tidâl delapan kali, sujud delapan kali. Sugesti al-hamd, akan membangun mental untuk selalu pandai bersyukur, 'abdan syakâra'. Selayaknya, manusia tidak hanya pandai meminta, tetapi juga harus pandai berterima kasih. Sugesti al-hamd, menjadikan mental seseorang selalu bahagia dan merasa senantiasa menjadi orang beruntung, sehingga kesedihan tidak merasuki jiwanya. Sugesti al-Hamd dapat mencetak kepribadian dan kesadaran bahwa ada campur tangan Allah SW'T dan partisipasi orang lain dalam menciptakan kesuksesan dan kebahagiaan, sehingga orang yang merasa suskes tidak egois. Jika orang sukses masih egois, maka ia sebetulnya belum sukses, terutama dalam mengatasi masalah egoisnya.

\section{SIMPULAN}

Faktor utama pembentuk akhlak seseorang bukan genetika/keturunan tetapi lingkungan, baik lingkungan keluarga, sekolah dan masyarakat. Ketiga lingkungan tersebut identik dengan pendidikan. Karena itu, pendidikan apa pun (termasuk pendidikan akhlak) senantiasa melibatkan ketiga lingkungan tersebut secara utuh dan menyeluruh. Lingkungan yang baik dapat membentuk akhlak yang baik.

Telaah pendidikan akhlak dapat ditempuh yaitu melalui; 1) teologis/dogma/agama dan 2) filosofis/rasio/akal maupun gabungan dari keduanya. Bagaimanapun juga, agama dengan filsafat tidak akan bertentangan sebab pada dasarnya keduanya berasal dari Allah SWT.

Secara metodis, pendidikan akhlak dapat ditempuh melalui pendekatan induktif dan pendekatan deduktif. Pendekatan induktif mendasarkan pada asumsi bahwa guru adalah cermin bagi anak dalam berperilaku. Hal-hal yang baik yang dilakukan oleh guru dapat ditiru oleh anak. Sebaliknya, hal yang buruk yang dialami oleh guru dapat dihindari oleh murid. Pendekatan deduktif berasumsi bahwa secara normatif al-Qur'an dan hadis berisi kebenaran dan kebaikan. Dengan demikian, guru dapat mendoktrinkan konsep-konsep kebaikan yang masih abstrak tersebut dengan mengondisikan murid untuk selalu terbiasa melakukan perbuatan baik.

Aspek peribadatan yang banyak mengandung unsur pendidikan akhlak adalah shalat. Pada dasarnya shalat tidak mengenal waktu. Sepanjang sejarah manusia ada dimuka bumi, shalat senantiasa diperintahkan kepada seluruh manusia. Dalam seluruh bacaan shalat terdapat auto sugesti yang mampu membimbing manusia mengucapkan secara berulang-ulang perkataan-perkataan baik, sehingga pada gilirannya perkataan tersebut merasuk kealam bawah sadarnya dan secara refleks terwujud dalam perbuatan yang positif. 


\section{DAFTAR PUSTAKA}

Amin, Ahmad. t.t. Kitâb al-Akblâq. Cairo: Dar al-Kutb al-Mishriyah.

Anis, Ibrahim. 1972. Al-Mu'jamât. Mesir: Dar al-Ma'ari.

Daradjat, Zakiah. 1977. Membina Nilai-nilai Moral di Indonesia. Cet. IV. Jakarta: Bulan Bintang.

Hanafi, Hasan. 2009. Hermeneutikea al-Qur'an. Penerjemah Yudian Wahyudi dan Hamdiah Latif. Yogyakarta: Nawesea.

Haryanto, Sentot. 2003. Psikologi Shalat. Cet. III. Yogyakarta: Pustaka Pelajar.

Isa, Abdul Qadir. 2005. Hakekat Tasauf. Terj. Khairul Amru Harahap dan Afrizal Lubis. Jakarta: Qisthi Press.

Jabbar, Umar Abdul. t.t. Khulâsat Nur al-Yaqîn. Surabaya: Salim Nihan.

Kartanegara, Mulyadi. 2005. The Best Chicken Soup of the Philosopehers. Bandung: Hikmah.

Khaldun, Ibn. Tarikh Ibn Khaldun. Juz I. Maktabah Syamilah.

Miskawaih, Ibn. 1999. Menuju Kesempunaan Akhlak. Terjemahan Helmi Hidayat. Cet. IX. Bandung: Mizan.

Nasution, Harun.1995. Falsafah dan Mistisisme dalam Islam. Cet. IX. Jakarta: Bulan Bintang.

------, 1986.Teologi Islam: Aliran-Aliran Sejarah Analisa Perbandingan. Cet. V. Jakarta: UI Press.

Purbakarwatja, Soegarda. 1978. Ensiklopedi Pendidikan. Jakarta: Gunung Agung.

Rachman, Budhy Munawar (Ed.). 1995. Kontekstualisai Doktrin Islam Dalam Sejarah. Jakarta: Paramadina.

Ridha, Muhammad Rasyid. 1365 H.Tafsîr al-Manâr.Jilid V. Cairo: Dar al-Manar.

Ridha, Muhammad Rasyid. 1365 H. Tafsîr al-Manâr. Jilid IV. Cairo: Daar alManar.

Ridha, Muhammad Rasyid. Tafsir al-Manar. Maktabah Syamilah. Juz 4.

Sabtani, Muhammad Hasan. Atsaru Ta'lim al-Qur'an al-Karim 'Ala al-Fardi wa alMujtama’. Juz I. Maktabah Syamilah.

Shihab, Quraish. 1997. Wawasan al-Qur'an. Cet. V. Bandung: Mizan.

www.al-mostafa.com

Yunus, Mahmud. 1407 H. Al-Tarbiyah wa al-Ta'lim. Juz I A. Gontor: Darussalam Press.

Yunus, Mahmud. t.t. At-Tarbiyah wa al-Ta'lîm. Juz I B. Gontor: Darussalam Press

Zuqzuq, Mahmud Hamdi.1983. Muqaddimah fî Ilmi al-Akhlâq. Kuwait: Darul Qalam. 